\title{
DRUG THERAPY IN AUTOIMMUNE THYROIDITIS
}

\author{
Michael I. SHEREMET ${ }^{1 凶}$, Viktor 0. SHIDLOVSKYI ${ }^{2}$, Anatoly D. BEDENYUK ${ }^{2}$, \\ Oleksandr V. SHIDLOVSKYI ${ }^{2}$, Vitaliy V. MAKSYMYUK ${ }^{1}$, Nina P. TKACHUK ${ }^{1}$, Victor M. BATIG ${ }^{3}$, \\ Tetiana A. GLUSHCHENKO ${ }^{3}$, Ivanna I. ABRAMCHUK ${ }^{3}$, Igor A. MALISHEVSKY ${ }^{4}$
}

${ }^{1}$ Surgery Department No1, Bukovinian State Medical University, Ukraine

${ }^{2}$ Surgery Department, I.Y. Horbachevsky State Medical University, Ukraine

${ }^{3}$ Department of Therapeutic Stomatology, Bukovinian State Medical University

${ }^{4}$ Department of Oncology and Radiology, Bukovinian State Medical University, Ukraine

Received 15 June 2018, Accepted 29 July 2018

https://doi.org/10.31688/ABMU.2018.53.3.10

\section{Abstract}

Background. Autoimmune thyroiditis (AIT) is one of the unsolved problems of modern endocrinology, the etiology and pathogenesis being still insufficiently known.

Objectives. To study the effects of substitution, antioxidant and lymph-drainage therapy on the structure and function of the thyroid gland in patients with AIT and hypothyroidism.

Methods. We have identified 2 groups of patients with AIT and subclinical hypothyroidism. The first group - control group - included 20 patients who received substitution therapy with thyroxine. The second group included 33 patients who received a comprehensive treatment with thyroxine, alpha lipoic acid and Lymphomyosot.

Results. The use of substitution therapy with thyroxine and the proposed antioxidant and lymph drainage therapy in patients with AIT led to the improvement of the structure of the gland, reduced the activity of peroxide oxidation processes and the activity of pro-inflammatory cytokines, increased the level of antioxidant defense enzymes, normalized the number of aniline-positive lymphocytes, improved the lymphatic drainage function of the gland. Our results sustain the

\section{RÉsumé}

La thérapie medicamenteuse de la thiroidite auto-immune

Introduction. La thyroïdite auto-immune est l'un des problèmes non résolus de l'endocrinologie moderne, car la question de son étiologie et de sa pathogénie est insuffisamment connue.

Objectifs. Etudier l'effet de la substitution, de la thérapie antioxydante et de drainage lymphatique chez les patients atteints d'AIT avec hypothyroïdie sur la structure et l'état fonctionnel de la glande thyroïde et le cours des processus auto-immuns.

Méthodes Pour évaluer l'efficacité de la substitution, de la thérapie antioxydante et du drainage lymphatique afin de stabiliser l'état fonctionnel de la thyroïde et de supprimer l'activité des processus auto-immuns, nous avons identifié 2 groupes de patients atteints de thyroïdite auto-immune avec hypothyroïdie subclinique. Dans le groupe I (de contrôle) ont été inclus 20 patients qui ont reçu un traitement de substitution avec de la thyroxine. Dans le groupe II ont été inclus 33 patients qui ont reçu un traitement complet avec l'utilisation de la thyroxine, l'acide alpha-lipoïque et Lymphomyosot conformément au schéma élaboré. 
effectiveness of the proposed method of complex treatment in patients with autoimmune thyroiditis.

Keywords: autoimmune thyroiditis, antioxidant, lymph-drainage therapy.

Abbreviations: AIT - autoimmune thyroiditis; PO peroxide oxidation; AOD - antioxidant defense; ALA - alpha lipoic acid.

\section{INTRODUCTION}

Autoimmune thyroiditis (AIT) is one of the most common autoimmune diseases ${ }^{1}$. The incidence of AIT is increasing and accounts for a significant proportion of all thyroid pathology $y^{1,2}$. Hypothyroidism is one of the most common consequence of AIT. The high prevalence of hypothyroidism, along with the nonspecific symptoms of this disease, underline the great medical significance of AIT ${ }^{3,4}$. Despite the importance of this pathology, until now there have not been effective methods of treatment of AIT or a unanimous opinion of specialists regarding the treatment of immunological disorders that will lead to AIT.

Free radical oxidation plays an important role in the development of cytodestructive processes in the pathogenesis of a large number of diseases, including autoimmune diseases of the thyroid gland. $\mathrm{PO}$ products can inhibit the synthesis of proteins, cause polymerization of the protein components of the membrane and DNA bases and alter vascular patency, inflammatory reaction and chemotactic activity of cells $s^{5-11}$. Damage to nucleic acids usually occurs due to oxidative degradation of their bases and deoxyribose's, which are involved in the formation of cross-links ${ }^{12-17}$. Damage to the cytoplasmic membrane and the DNA of the immunocompetent cells that regulate the strength of the immune response is the greatest danger, mediated by the free radicals. These processes cause their premature death and breakdown of immunological tolerance, with the appearance of autoimmune reactions and persistence of chronic inflammation ${ }^{18-19}$.

AIT is characterized by severe thyroid infiltration by lymphocytes, neutrophils and macrophages,
Résultats. L'utilisation d'une thérapie de substitution avec la thyroxine et le traitement de drainage lymphatique et anxioïdien proposé chez les patients atteints d'AIT favorise l'amélioration de la structure de la glande, réduit l'activité des processus d'oxydation des peroxydes et l'activité des cytokines pro-inflammatoires, augmente le niveau d'enzymes de défense antioxydantes, normalise le nombre de lymphocytes positifs à l'aniline, améliore la fonction de drainage lymphatique de la glande, le traitement de substitution par la thyroxine ou ne l'applique pas. Tout cela témoigne de l'efficacité de la méthode proposée de traitement complexe des patients atteints de thyroïdite auto-immune.

Mots-clés: thyroïdite auto-immune, thérapie antioxydante et drainage lymphatique.

indicating the inflammatory response $\mathrm{e}^{19,20}$. These processes are confirmed by an increase in the number of pro-inflammatory cytokines that produce T-lymphocytes and macrophages. T-cytotoxic cells in interaction with thyroid cause their destruction ${ }^{21-24}$. There is a vicious circle of interaction between cellular and humoral responses, which cause intensification of damaging reactions in the thyroid gland and reduce its functional activity. In this regard, there is no doubt that studying the susceptibility of lymphocytes to apoptosis and the mechanisms of cell proliferation modulation will help explain the pathogenesis of autoimmune thyroiditis and to develop pathophysiological approaches, to optimize the treatment of this disease $\mathrm{e}^{25,26}$.

Adequate and complete functioning of lymph drainage mechanisms is an essential condition for maintaining an organism's homeostasis, ensuring its vital functions. Effective lymph drainage of the intercellular matrix facilitates the restoration of impaired interaction of the immune-endocrine system with the cells and tissues, in particular, the thyroid gland ${ }^{27}$.

The goal of substitution hormone therapy in hypothyroidism, as a consequence of AIT, is the achievement of medication euthyroidism. In addition to standard substitution therapy, special attention is given to complex treatment with the use of drugs that regulate the activity of the $\mathrm{PO}$ and the system of antioxidant protection and improve lymph circulation in the thyroid gland. Such an integrated approach to treatment of AIT is supposed to have a positive effect $^{27,28}$

There are reports of a positive effect from the use of ALA as a universal antioxidant, which functions on the membrane and inside the cell. ALA is a potent endogenous vitaminoid-antioxidant that 
regulates the metabolism of the body, participating as a coenzyme in the Krebs cycle ${ }^{19}$. Considering these pharmacological properties of ALA, it is possible to expect a positive effect of its application for the treatment of AIT. There are few reports in the literature on the use of ALA in the treatment of AIT, and its results have different interpretations, which should be considered as approbations ${ }^{29,30}$.

Activating lymph drainage and restoring self-regulating processes in the thyroid tissue is an important and primary task, from the point of view of bioregulation approach to the treatment of $\mathrm{AIT}^{20}$.

To achieve these goals and objectives, we used a comprehensive anti-homotoxic medication called lymphomyosot. According to the literature, its administration improves the drainage of the intercellular space, function of the immune and endocrine systems, activates lymph outflow and transport function of the matrix, normalizes immunological protection of the body, restores homogeneity in the matrix ${ }^{26,28}$. At the same time there are additional positive effects: increased bioavailability of medications, shortening their application term, minimizing their side effects ${ }^{29,30}$.

A brief analysis of literature data regarding the pathogenic substantiation of AIT treatment suggests that the treatment should be comprehensive and multi-purpose. This means that it should be aimed at drug-mediated compensation of hypothyroidism, improvement of lymph outflow from the thyroid gland and reduction of lymphoid infiltration, correction of lipid peroxidation and AOD processes.

The obJective OF the Study was to establish the effect of substitution, antioxidant and lymph drainage therapy on the structure and functional state of the thyroid gland in patients with AIT and hypothyroidism.

\section{Material AND Methods}

The study involved 53 women aged between 26 - 62 years, with autoimmune thyroiditis, who were examined between January 2014 -December 2016 in the Chernivtsi Regional Endocrinological Dispensary, Ukraine.

To evaluate the effectiveness of substitution, antioxidant and lymph drainage therapy in order to stabilize the functional state of the thyroid gland and suppress the activity of autoimmune processes, the patients with autoimmune thyroiditis with subclinical hypothyroidism were divided into two groups. The first group (control) included 20 patients who received substitution therapy with thyroxine preparations. The second group included 33 patients who received comprehensive treatment using thyroxine preparations, ALA and lymphomyosot in accordance with the developed scheme.

The activity of peroxide oxidation (PO) and the state of antioxidant systems (AOS) was assessed before the treatment, after 6 months and after 3 years, in both groups, by determining the degree of oxidative modification of proteins (OMP), the activity of ceruloplasmin (CP) in the serum, the content of malonic aldehyde (MA), the activity of glutathione peroxidase (GPx), and catalase in erythrocytes, by conventional methods. In addition, the hormonal function of the thyroid gland, the level of antibodies to thyroperoxidase (AbTPO) were studied, as well as structural changes in the gland (volume of the gland, nodular formation), by ultrasound examination.

The content of lymphocytes bearing the apoptosis marker, the CD95 + receptor, the level of apoptosis in the population of peripheral blood lymphocytes, the content of tumor necrosis factor- $\alpha$ (TNF- $\alpha$ ), the concentration of interferon- $\gamma($ IFN- $-\gamma)$ and interleukin-1 $\beta$ (IL-1 $\beta$ ) were studied, too. These indicators were studied by means of standard diagnostic kits, with the technology recommended by the manufacturer.

In order to have a comparative assessment, the same indicators were studied in 25 healthy women, aged 21 to 42 years.

The scheme of treatment included thyroxine preparations in an individual dose, which provided the level of TSH within the reference values from 0.4 to $4.0 \mu \mathrm{IU} / \mathrm{mL}$. ALA was administered in courses according to the standard scheme - 300 units per day for 10 days, then the tablets were dosed for 300 units for three months, with a repetition after six months. Lymphomyosot was administered $1.1 \mathrm{ml}$ intramuscularly for five days, followed by five more injections every four days, and then 10 drops three times a day, sublingually ( $30 \mathrm{ml}$ per course), were administered. Repeated administration of the drug was carried out every three months - five injections every four days, with the continuation of its sublingual administration.

\section{Results AND DISCUSSION}

The results of laboratory tests showed that patients from both groups had almost identical clinical manifestations of AIT with hypothyroidism and changes in the studied parameters before the treatment.

Six months after the treatment, the general condition of patients in both groups improved. However, the patients in the control group continued to feel pressure on the anterior surface of the neck and 
suffered from dry cough. The patients in the main group, with rare exceptions, did not have complaints and considered themselves to be healthier. At the same time, the levels of MA and OMP decreased in patients of the control group and did not change in the second one. In general, the changes in the mean values are not reliable. In patients of the main group, in all cases, a decrease in the level of MA and OMP was noted. The changes are reliable in the mean values compared to those before the observation ( $p$ $<0,05$, Table 1).

After three years, all the patients were examined. In the control group, part of the patients subjectively noticed a deterioration of their general condition: the thickening of the front surface of the neck increased, they kept feeling general fatigue, their body weight increased. 14 patients had an increase in MA by 1.5-4.8 $\mu \mathrm{mol} / \mathrm{L}$ and OMP by 5.1-7.9 u.o.d (units of optical density)./g of protein, and in 6 cases they practically did not change. According to the mean values in the group as a whole, compared to those of 6 months of observation, the changes are significant. Patients in the main group considered themselves healthy for this period of examination. Their general state did not change compared to that during six months of treatment. According to the results of laboratory tests, in comparison with the values for the period of 6 months of observation the levels of MA and OMP in 26 patients decreased by $1.3-2.7 \mu \mathrm{mol} / \mathrm{L}$ and by 4.2 - 7.8 u.o.d./g of protein respectively, and in 7 patients they increased by $0.9-1.8 \mu \mathrm{mol} / \mathrm{L}$ and by $3.1-4.2$ u.o.d./g of protein. In general, in the group of patients, the indices of both MA and OMP decreased in the mean values $(\mathrm{M} \pm \mathrm{m})$, compared with the data for the period of 6 months of observation, the changes are reliable $(\mathrm{p}<0,05$, Table 1$)$.

Therefore, the studied parameters of activity of processes of $\mathrm{PO}$ in patients with AIT, during 6 months and 3 years of follow-up, in patients from the control group, indicate a gradual evolution of these processes, and in patients of the main group - their significant decrease.

While studying the activity of AOD enzymes in patients from the control and study groups prior to their admission to hospital, the reduction of these indicators in comparison with control patients was established (Table 2).

After 6 months of follow-up, in 16 patients in the control group, catalase levels increased by 3.9 $9.7 \mu \mathrm{mol} / \mathrm{min} \cdot \mathrm{g}$, while in 4 cases they practically did not change; in 18 patients, the ceruloplasmin level increased by $1.9-6.8$, and in 3 of them it decreased by $0.5-1.7$ u.o.d./g of protein; the level of GPx in 17 patients increased by $4.5-8.8 \mu \mathrm{mol} / \mathrm{min}$ - ng, and in 3 of them it did not change significantly compared with the rates before the admission. After 3 years of treatment in the control group of patients, the activity of the AOD enzymes continued to increase. The catalase level in 16 patients increased by 3.5-7.6 $\mu \mathrm{mol} / \mathrm{min} \cdot \mathrm{g}$ of protein, and in 4 of them it decreased by $1.3-4.1 \mu \mathrm{mol} / \mathrm{min} \cdot \mathrm{g}$ of protein. The level of ceruloplasmin in 18 patients increased by 1.8-5.7 u.o.d./ g of protein, and in 2 patients it practically did not change for 6 months; the level of GPx in 16 cases increased by $3.8-7.7 \mu \mathrm{mol} / \mathrm{min} \cdot \mathrm{ng}$, and in 4 patients, it was at the level of the values for the period of 6 months of treatment.

In the control group, the mean value $(\mathrm{M} \pm \mathrm{m})$ of catalase, ceruloplasmin and GPx increased for the period of 6 months and 3 years of observation, compared with those before the treatment. The changes are reliable only for the catalase value (Table 2).

In the main group, the catalase increased in 28 patients in the range from 4.5 to $28.5 \mu \mathrm{mol} / \mathrm{min} \cdot \mathrm{g}$ of $\mathrm{Hb}$ during 6 months of treatment and in 5 patients this value remained at the previous level. The content of ceruloplasmin in 27 patients increased by 5,2 to 21,7 u.o.d./ g of protein, in 3 of them it decreased by 2,7 to 3,4 u.o.d./ $\mathrm{g}$ of protein and in 3 of them it remained at the previous level. The activity of GPx in 24 patients increased in some cases by $8.9-42.7$ $\mu \mathrm{mol} / \mathrm{min} \cdot \mathrm{g}$ of $\mathrm{Hb}$, in 6 patients it decreased by $4.7-11.5 \mu \mathrm{mol} / \mathrm{min} \cdot \mathrm{g}$ and in other 3 it did not change. 3 years after the treatment, compared to the values of 6 months, the activity of catalase in 29 patients increased by $4.6-24.3 \mu \mathrm{mol} / \mathrm{min} \cdot \mathrm{g}$ of $\mathrm{Hb}$, in 2 patients it decreased by 2.6 and $-4.3 \mu \mathrm{mol} /$ min $-\mathrm{g}$ of $\mathrm{Hb}$ and in other two it did not change. The level of ceruloplasmin in 30 patients increased by 11.2 to 23.4 u.o.d./ g of protein and in 3 cases it did not change. The GPx activity in 25 patients increased from 8.6 to $31.2 \mu \mathrm{mol} / \mathrm{min} \bullet$ of $\mathrm{Hb}$, in 5 cases it decreased from 4.8 to $9.2 \mu \mathrm{mol} / \mathrm{min} \cdot \mathrm{g}$ of $\mathrm{Hb}$ and in 3 cases it remained unchanged. In general, the mean values $(\mathrm{M} \pm \mathrm{m})$ of catalase, ceruloplasmin and GPx increased compared with the values for the 6 months of observation, indicating the positive effect of treatment on the activity of the blood AOD system $\mathrm{p}<0.05$ (Table 2).

Therefore, the studied blood AOD values in patients with AIT for 6 months and 3 years of follow-up in patients from the control group indicate a mild and insignificant increase in AOD rates, and in patients from the main group their significant growth.

Studying apoptosis values found a significant decrease in the number of annexin V-presenting lymphocytes. This proves the suppression of apoptosis. The correlation between the number of annexin V-presenting lymphocytes with an increased number of CD95 + lymphocytes prepared for apoptosis 
Table 1. Indicators of peroxide oxidation of blood in patients with autoimmune thyroiditis before and after the treatment

\begin{tabular}{|c|c|c|c|c|c|c|c|}
\hline \multirow[b]{2}{*}{ Values } & \multirow[b]{2}{*}{$\begin{array}{c}\text { Donors } \\
(\mathrm{n}=25)\end{array}$} & \multicolumn{3}{|c|}{ Control $(n=20)$} & \multicolumn{3}{|c|}{ Main $(n=33)$} \\
\hline & & On admission & $\begin{array}{c}\text { After } 6 \\
\text { months of } \\
\text { treatment }\end{array}$ & $\begin{array}{l}\text { After } 3 \text { years } \\
\text { of treatment }\end{array}$ & On admission & $\begin{array}{c}\text { After } 6 \\
\text { months of } \\
\text { treat-ment }\end{array}$ & $\begin{array}{l}\text { After } 3 \text { years } \\
\text { of treatment }\end{array}$ \\
\hline $\begin{array}{c}\mathrm{MA} \\
\mu \mathrm{mol} / \mathrm{L}\end{array}$ & $\begin{array}{l}8.2 \pm \\
0.34\end{array}$ & $\begin{array}{c}14.2 \pm 0.29 \\
\mathrm{p}^{*}\end{array}$ & $\begin{array}{c}12.8 \pm \\
0.12 \\
\mathrm{p}^{* *} \\
\end{array}$ & $\begin{array}{c}13.9 \pm 0.28 \\
\mathrm{p}^{* * *}\end{array}$ & $\begin{array}{c}13.9 \pm 0.28 \\
\mathrm{p}^{*}\end{array}$ & $\begin{array}{c}10.2 \pm \\
0.15 \\
\mathrm{p}^{* *}\end{array}$ & $\begin{array}{c}8.1 \pm 0.19 \\
p^{* * *}\end{array}$ \\
\hline $\begin{array}{c}\text { OMP } \\
\text { u.o.d./g of } \\
\text { protein }\end{array}$ & $\begin{array}{l}39.6 \pm \\
1.13\end{array}$ & $\begin{array}{c}67.3 \pm 1.12 \\
\mathrm{p}^{*}\end{array}$ & $\begin{array}{c}62.2 \pm 1.18 \\
\mathrm{p}^{* *}\end{array}$ & $\begin{array}{c}65.6 \pm 1.05 \\
\mathrm{p}^{* * *}\end{array}$ & $\begin{array}{c}66.8 \pm 1.27 \\
\mathrm{p}^{*}\end{array}$ & $\begin{array}{c}51.2 \pm 1.23 \\
\mathrm{p}^{* *}\end{array}$ & $\begin{array}{c}45.8 \pm 1.12 \\
\mathrm{p}^{* * *}\end{array}$ \\
\hline
\end{tabular}

Note. $\mathrm{p}^{*}$ - compared to donors, $\mathrm{p}^{* *}$ - compared to the values on admission, $\mathrm{p}^{* * *}$ - compared to the values after 6 months of treatment, $\mathrm{p}<0,05$.

Table 2. The rates of blood antioxidant defense in patients with AIT before and after the treatment

\begin{tabular}{|c|c|c|c|c|c|c|c|}
\hline \multirow[b]{2}{*}{ Value } & \multirow[b]{2}{*}{$\begin{array}{l}\text { Donors } \\
(n=25)\end{array}$} & \multicolumn{3}{|c|}{ Control $(n=20)$} & \multicolumn{3}{|c|}{ Main $(n=33)$} \\
\hline & & On admission & $\begin{array}{l}\text { After } 6 \\
\text { months of } \\
\text { treatment }\end{array}$ & $\begin{array}{c}\text { After } 3 \text { years of } \\
\text { treatment }\end{array}$ & On admission & $\begin{array}{l}\text { After } 6 \\
\text { months of } \\
\text { treatment }\end{array}$ & $\begin{array}{l}\text { After } 3 \text { years } \\
\text { of treatment }\end{array}$ \\
\hline $\begin{array}{c}\text { Catalase, } \\
\mu \mathrm{mol} / \\
\min \bullet \mathrm{g} \text { of } \mathrm{Hb}\end{array}$ & $\begin{array}{c}168.7 \pm \\
3.40\end{array}$ & $\begin{array}{c}128.5 \pm 3.69 \\
\mathrm{p}^{*}\end{array}$ & $134.7 \pm 3.19$ & $\begin{array}{c}142.7 \pm 3.43 \\
\mathrm{p}^{* * *}\end{array}$ & $\begin{array}{c}127.8 \pm 3.72 \\
\mathrm{p}^{*}\end{array}$ & $\begin{array}{c}149.7 \pm 3.33 \\
\mathrm{p}^{* *}\end{array}$ & $\begin{array}{c}165.3 \pm 3.72 \\
\mathrm{p}^{* * *}\end{array}$ \\
\hline $\begin{array}{c}\text { Ceruloplasmin, } \\
\text { u.o.d./g of } \\
\text { protein }\end{array}$ & $\begin{array}{l}77.2 \pm \\
2.61\end{array}$ & $\begin{array}{c}42.1 \\
\pm 2.87 \\
\mathrm{p}^{*} \\
\end{array}$ & $46.8 \pm 2.12$ & $49.2 \pm 2.84$ & $\begin{array}{c}43.1 \\
\pm 2.79 \\
\mathrm{p}^{*} \\
\end{array}$ & $\begin{array}{c}58.6 \pm 2.78 \\
\mathrm{p}^{* *}\end{array}$ & $\begin{array}{c}75.4 \pm 2.07 \\
\mathrm{p}^{* * *}\end{array}$ \\
\hline $\begin{array}{c}\text { GPx, } \\
\mu \mathrm{mol} / \mathrm{min} \bullet \mathrm{g} \\
\text { of } \mathrm{Hb}\end{array}$ & $\begin{array}{l}205.0 \pm \\
3.73\end{array}$ & $\begin{array}{c}142.3 \pm 3.88 \\
\mathrm{p}^{*}\end{array}$ & $148.6 \pm 3.81$ & $153.1 \pm 3.51$ & $\begin{array}{c}143.8 \pm 3.91 \\
\mathrm{p}^{*}\end{array}$ & $\begin{array}{c}173.8 \pm 3.32 \\
\mathrm{p}^{* *}\end{array}$ & $\begin{array}{c}196.8 \pm 3.76 \\
\mathrm{p}^{* * *}\end{array}$ \\
\hline
\end{tabular}

Note. $\mathrm{p}^{*}$-compared to donors, $\mathrm{p}^{* *}$ - compared to values on admission, $\mathrm{p}^{* * *}$ - compared to values after 6 months of treatment, $\mathrm{p}<0,05$.

confirms the probability of a disorder in the realization of Fas-induced apoptotic loss of lymphocytes in AIT. In addition, there was a reliable increase in the level of pro-inflammatory cytokines TNF- $\alpha$, INF- $\gamma$ and IL-1 $\beta$ in the blood serum.

Regarding the apoptosis rate in the patients of the control group, after 6 months of treatment the CD95 + content decreased by $1.5-4.2 \%$ in $23 \mathrm{pa}-$ tients; in 4 of them it increased by $0.8-2.7 \%$ and in 6 cases it remained the same. The percentage of annexin $\mathrm{V}+$ lymphocytes in 25 patients decreased by $0.3-3,2 \%$, in 5 cases it increased by $0.2-1.4 \%$ and in 3 patients it did not change. The activity of pro-inflammatory cytokines, including the content of TNF- $\alpha$, decreased in 27 patients by $0.2-1.1 \mathrm{pg} / \mathrm{mL}$, in 3 cases it did not change and in other 3 it increased by $0.2-0.5 \mathrm{pg} / \mathrm{mL}$; the concentration of INF- $\gamma$ in 25 patients decreased by $0.2-1.5 \mathrm{pg} / \mathrm{mL}$, in 3 cases it increased by $0.1-0.4 \mathrm{pg} / \mathrm{mL}$ and in 5 patients it remained unchanged; the level of IL - $1 \beta$ in 24 patients decreased by $0.1-0.4 \mathrm{pg} / \mathrm{mL}$, in 6 cases it increased by $0.1-0.2 \mathrm{pg} / \mathrm{mL}$ and in 3 patients it did not change.
After 3 years of treatment, compared with 6 months, the concentration of CD95 + lymphocytes in $23 \mathrm{pa}$ tients decreased by $1.1-2.3 \%$, in 6 cases it remained at the previous level and in 4 patients it increased by 0 , $4-0.9 \%$. The number of annexin $\mathrm{V}+$ lymphocytes in 25 patients decreased by $0.3-1.7 \%$, in 3 of them it increased by $0.3-0.9 \%$ and in 5 cases it did not change. There was also a decrease in the activity of prostatic cytokines. In particular, the concentration of TNF- $\alpha$ in 19 patients decreased by $0.3-0.9 \mathrm{pg} /$ $\mathrm{mL}$, in 9 cases it increased by $0.2-0.5 \mathrm{pg} / \mathrm{mL}$ and in 5 patients it remained unchanged; the content of INF- $\gamma$ in 22 patients decreased by $0.3-1.8 \mathrm{pg} / \mathrm{mL}$, in 4 of them it did not change and in 7 cases it increased by $0.3-0.6 \mathrm{pg} / \mathrm{mL}$; the level of IL - $1 \beta$ in 25 patients decreased from $0.1-0.6 \mathrm{pg} / \mathrm{mL}$, in 3 of them it remained unchanged, in other 5 it increased by $0.2-0.5$ $\mathrm{pg} / \mathrm{mL}$. In general, the treatment in the control group, according to the results of the study at 6 months and 3 years follow-up, contributed to a decrease in the activity of the apoptosis system, but these changes are not reliable for all investigated parameters. 
Table 3. Peripheral blood lymphocyte apoptosis and concentration of TNF- $\alpha$, INF- $\gamma$ and IL-1 $\beta$ in blood serum from donors and patients with autoimmune thyroiditis, before and after treatment.

\begin{tabular}{|c|c|c|c|c|c|c|c|}
\hline \multirow[b]{2}{*}{ Values } & \multirow[b]{2}{*}{$\begin{array}{l}\text { Donors } \\
(n=25)\end{array}$} & \multicolumn{3}{|c|}{ Control $(n=20)$} & \multicolumn{3}{|c|}{ Main $(n=33)$} \\
\hline & & On admission & $\begin{array}{l}\text { After } 6 \\
\text { months of } \\
\text { treatment }\end{array}$ & $\begin{array}{l}\text { After } 3 \text { years } \\
\text { of treatment }\end{array}$ & On admission я & $\begin{array}{l}\text { After } 6 \\
\text { months of } \\
\text { treatment }\end{array}$ & $\begin{array}{c}\text { After } 3 \text { years of } \\
\text { treatment }\end{array}$ \\
\hline $\begin{array}{l}\text { CD95 + lympho- } \\
\text { cytes, } \%\end{array}$ & $\begin{array}{c}11,6 \\
\pm 0,58\end{array}$ & $\begin{array}{c}25,1 \pm 0,65 \\
\mathrm{p}^{*} \\
\end{array}$ & $\begin{array}{c}23,3 \pm \\
0,57 \\
\end{array}$ & $\begin{array}{c}21,6 \pm \\
0,54 \\
\end{array}$ & $\begin{array}{c}24,9 \pm \\
0,61 \\
p^{*} \\
\end{array}$ & $\begin{array}{c}17,3 \\
\pm 0,59 \\
\mathrm{p}^{* *} \\
\end{array}$ & $\begin{array}{c}12,8 \\
\pm 0,52 \\
\mathrm{p}^{* * *} \\
\end{array}$ \\
\hline $\begin{array}{c}\text { Number of } \\
\text { annexin V + } \\
\text { lymphocytes,\% }\end{array}$ & $\begin{array}{c}17,5 \\
\pm 0,39\end{array}$ & $\begin{array}{c}12,8 \\
\pm 0,31 \\
\mathrm{p}^{*}\end{array}$ & $\begin{array}{l}11,5 \pm \\
0,27\end{array}$ & $\begin{array}{l}10,3 \pm \\
0,23\end{array}$ & $\begin{array}{c}12,9 \\
\pm 0,28 \\
\mathrm{p}^{*} \\
\end{array}$ & $\begin{array}{c}15,8 \\
\pm 0,26 \\
\mathrm{p}^{* *} \\
\end{array}$ & $\begin{array}{c}16,8 \\
\pm 0,28 \\
\mathrm{p}^{* * *} \\
\end{array}$ \\
\hline $\begin{array}{l}\text { Concentration of } \\
\text { TNF- } \alpha, p g / m L\end{array}$ & $\begin{array}{c}1,6 \\
\pm 0,27\end{array}$ & $\begin{array}{c}5,2 \\
\pm 0,24 \\
\mathrm{p}^{*} \\
\end{array}$ & $\begin{array}{l}4,9 \pm \\
0,31\end{array}$ & $\begin{array}{l}4,7 \pm \\
0,33\end{array}$ & $\begin{array}{c}5,2 \\
\pm 0,29 \\
\mathrm{p}^{*}\end{array}$ & $\begin{array}{c}3,4 \\
\pm 0,28 \\
p^{* *}\end{array}$ & $\begin{array}{c}2,3 \\
\pm 0,29 \\
\mathrm{p}^{* * *}\end{array}$ \\
\hline $\begin{array}{l}\text { Concentration of } \\
\text { INF- } \gamma, \mathrm{pg} / \mathrm{mL}\end{array}$ & $\begin{array}{c}1,3 \\
\pm 0,11\end{array}$ & $\begin{array}{c}10,5 \\
\pm 0,29 \\
\mathrm{p}^{*} \\
\end{array}$ & $\begin{array}{l}9,4 \pm \\
0,24\end{array}$ & $\begin{array}{l}8,8 \pm \\
0,26\end{array}$ & $\begin{array}{c}10,5 \\
\pm 0,28 \\
\mathrm{p}^{*} \\
\end{array}$ & $\begin{array}{c}5,3 \\
\pm 0,27 \\
\mathrm{p}^{* *} \\
\end{array}$ & $\begin{array}{c}3,5 \\
\pm 0,28 \\
\mathrm{p}^{* * *} \\
\end{array}$ \\
\hline $\begin{array}{l}\text { Concentration of } \\
\text { IL-1 } \beta, \mathrm{pg} / \mathrm{mL}\end{array}$ & $\begin{array}{c}1,9 \\
\pm 0,13\end{array}$ & $\begin{array}{c}4,8 \\
\pm 0,17 \\
p^{*}\end{array}$ & $\begin{array}{l}4,6 \pm \\
0,19\end{array}$ & $\begin{array}{l}4,4 \pm \\
0,19\end{array}$ & $\begin{array}{c}4,7 \\
\pm 0,16 \\
p^{*} \\
\end{array}$ & $\begin{array}{c}3,3 \\
\pm 0,18 \\
\mathrm{p}^{* *} \\
\end{array}$ & $\begin{array}{c}2,1 \\
\pm 0,17 \\
\mathrm{p}^{* * *} \\
\end{array}$ \\
\hline
\end{tabular}

Note. $\mathrm{p}^{*}$-compared to donors, $\mathrm{p}^{* *}$ - compared to the values on admission, $\mathrm{p}^{* * *}$ - compared to the values after 6 months of treatment, $\mathrm{p}<0,05$.

Regarding apoptosis in patients from the study group, after 6 months of treatment, the content of CD95 + lymphocytes in 31 patients decreased by $3.5-11.2 \%$ and in 2 cases remained similar with the values before the treatment; the number of annexin $\mathrm{V}+$ lymphocytes increased in all patients by 1.7 $5.2 \%$. The activity of pro-inflammatory cytokines decreased. For instance, the TNF- $\alpha$ content in all cases decreased by $0.6-3.5 \mathrm{pg} / \mathrm{mL}$; the concentration of INF- $\gamma$ in all patients also decreased by $1.9-7.8 \mathrm{pg} /$ $\mathrm{mL}$; the level of IL - $1 \beta$ in 26 patients decreased by $0.6-3.4 \mathrm{pg} / \mathrm{mL}$, and in 7 cases it did not change. After 3 years of treatment, compared with 6 months treatment, all patients showed a decrease in the concentration of CD95+ lymphocytes and pro-inflammatory cytokines TNF- $\alpha$, INF- $\gamma$, IL-1 $\beta$ and an increase in the number of aniline $\mathrm{V}+$ lymphocytes (Table 3, $\mathrm{p}<0.05)$. Regarding apoptosis, it should be noted that the treatment of patients from the main group using thyroxin, lymph drainage and antioxidant therapy leads to a reliable decrease in the activity of apoptotic processes in the thyroid gland.

To assess the effectiveness of the proposed antioxidant and lymph drainage therapy in both groups of patients, the changes in the volume of the thyroid gland, the level of AbTPO and the dose of substitution therapy with L-thyroxine were compared before and after the treatment. An increase or decrease in the dose of substitution therapy reflects the level of hormones-producing function of thyroid gland.
In 12 patients from the control group, a decrease in thyroid volume was observed by $1.8-2.5 \mathrm{~cm}^{3}$ six months after the substitution therapy, and in $8 \mathrm{pa}-$ tients an increase in thyroid volume by $1.3-1.8 \mathrm{~cm}^{3}$. In general, the volume of the thyroid gland in the control group, compared with those on admission, according to the mean values $(\mathrm{M} \pm \mathrm{m})$ for 6 months, decreased from 23.1 to $22.2 \mathrm{~cm}^{3}$, the changes being significant $(\mathrm{p}<0.05)$. After 3 years, the volume of the thyroid gland in 15 patients increased from 4.8 to $10.4 \mathrm{~cm}^{3}$ and in 5 patients it decreased from 2.8 to $4.1 \mathrm{~cm}^{3}$. The thyroid gland looked spotty, with hyperechogenicity of the tissue and multiple connective tissue elements. Solitary nodules (according to the results of puncture biopsy from nodal colloid goiter) were diagnosed in four patients and pseudo nodules in three cases. After 3 years, in the control group, the mean volume of the thyroid gland increased by 5.1 $\mathrm{cm}^{3}$ compared to the values at 6 months ( $\mathrm{p}<0.05$ ).

Ultrasound examination found a decrease in the volume of the thyroid gland, from 1.7 to $3.2 \mathrm{~cm}^{3}$ in 25 patients of the study group, in 3 cases an increase from 1.4 to $3.7 \mathrm{~cm}^{3}$ and in 5 cases the volume of the gland did not change. In general, the mean values (M $\pm \mathrm{m}$ ) of the volume of the thyroid gland in the study group at 6 months, compared with those at inclusion, decreased significantly. Three years later, the volume of the gland decreased from 0.9 to $1.5 \mathrm{~cm}^{3}$ in $27 \mathrm{pa}$ tients, in 4 cases it increased by 1.7 to $3.3 \mathrm{~cm}^{3}$ and in 2 patients did not change compared with the values 
Table 4. Comparative assessment of the volume and functional state of the thyroid gland in patients with AIT before and after treatment.

\begin{tabular}{|c|c|c|c|c|c|c|c|}
\hline \multirow[b]{2}{*}{ Value } & \multirow[b]{2}{*}{$\begin{array}{l}\text { Donors } \\
(n=25)\end{array}$} & \multicolumn{3}{|c|}{ Control $(n=20)$} & \multicolumn{3}{|c|}{ Main (n=33) } \\
\hline & & On admission & $\begin{array}{l}\text { After } 6 \\
\text { months of } \\
\text { treatment }\end{array}$ & $\begin{array}{c}\text { After } 3 \text { years of } \\
\text { treatment }\end{array}$ & On admission & $\begin{array}{l}\text { After } 6 \text { months } \\
\text { of treatment }\end{array}$ & $\begin{array}{c}\text { After } 3 \text { years of } \\
\text { treatment }\end{array}$ \\
\hline $\begin{array}{l}\text { Thyroid volume } \\
\qquad\left(\mathrm{cm}^{3}\right)\end{array}$ & $\begin{array}{l}15.4 \pm \\
0.17\end{array}$ & $\begin{array}{c}23.1 \pm 0.29 \\
p^{*}\end{array}$ & $\begin{array}{c}22.2 \pm 0.29 \\
\mathrm{p}^{* *}\end{array}$ & $\begin{array}{c}27.3 \pm 0.27 \\
\mathrm{p}^{* * *}\end{array}$ & $\begin{array}{c}22.7 \pm 0.31 \\
\mathrm{p}^{*}\end{array}$ & $\begin{array}{c}19.2 \pm 0.28 \\
\mathrm{p}^{* *}\end{array}$ & $\begin{array}{c}18.1 \pm 0.26 \\
\mathrm{p}^{* * *}\end{array}$ \\
\hline AbTPO, U/ml & $\begin{array}{c}15.3 \\
\pm 0.17\end{array}$ & $\begin{array}{c}298.4 \\
\pm 14.91 \\
\mathrm{P}^{*}\end{array}$ & $\begin{array}{r}296.5 \\
\pm 15.12\end{array}$ & $\begin{array}{c}288.7 \\
\pm 14.86\end{array}$ & $\begin{array}{c}297.8 \\
\pm 15.87 \\
\mathrm{p}^{*}\end{array}$ & $\begin{array}{c}182.2 \pm 14.79 \\
\mathrm{p}^{* *}\end{array}$ & $\begin{array}{c}131.2 \pm 13.82 \\
\mathrm{p}^{* * *}\end{array}$ \\
\hline $\begin{array}{c}\text { Dose of } L \text { - thy- } \\
\text { roxin } \\
(\mu g / \text { day })\end{array}$ & - & $57.3 \pm 0.29$ & $\begin{array}{c}42.5 \\
\pm 0.28 \\
p^{* *}\end{array}$ & $\begin{array}{c}58.9 \pm 0.25 \\
\mathrm{p}^{* * *}\end{array}$ & $55.7 \pm 0.26$ & $\begin{array}{c}33.2 \pm 0.29 \\
\mathrm{p}^{* *}\end{array}$ & $\begin{array}{c}28.2 \pm 0.28 \\
\mathrm{p}^{* * *}\end{array}$ \\
\hline
\end{tabular}

Note. $\mathrm{p}^{*}$ - compared to donors, $\mathrm{p}^{* *}$ - compared to the values on admission, $\mathrm{p}^{* * *}$ - compared to the values after 6 months of treatment, $\mathrm{p}<0,05$.

for a period of six months of treatment. In 2 patients, the increase of the thyroid volume was associated with nodules: in one case, a true nodule in volume of $0.6 \mathrm{~cm}^{3}$ (based on the results of the puncture biopsy it was nodal colloidal goiter), and in the second case, a pseudo nodule up to $0,7 \mathrm{~cm}^{3}$. At ultrasonography, the structure of the thyroid gland was homogeneous, with a small amount of connective tissue elements, the echogenicity of the gland was moderately diffusely reduced.

The level of AbTPO in patients from the control group, after 6 months of treatment, decreased in 5 patients by $9-16 \mathrm{U} / \mathrm{mL}$, in 4 cases increased by $7-12$ $\mathrm{U} / \mathrm{mL}$ and in 11 patients did not change. The examination after three years of treatment found that the level of AbTPO in 12 patients decreased by $6-18$ $\mathrm{U} / \mathrm{mL}$, in 3 cases did not change and in other 5 increased by $9-18 \mathrm{U} / \mathrm{mL}$.

The patients in the study group showed a reliable decrease of the mean values of AbTPO compared with admission, after 6 months of treatment. In 28 cases, the level of antibodies decreased from 67 to $139 \mathrm{U} / \mathrm{mL}$, in 2 patients increased by 35 and $42 \mathrm{U} /$ $\mathrm{mL}$ and in 3 cases it remained unchanged. After three years of treatment, compared to the 6 months follow-up, a significant decrease of AbTPO was also observed: in 27 cases it decreased from 35 to $82 \mathrm{U} /$ $\mathrm{mL}$, in 4 cases remained unchanged, and in 2 cases ranged between 19 and $25 \mathrm{U} / \mathrm{mL}$.

The dose of substitution therapy with thyroxine, after 6 months of treatment, in 11 patients from the control group, did not change, in 4 cases it decreased by 12.5 micrograms and in 5 patients it increased by 25 micrograms per day. After three years of treatment, the dose of substitution therapy in all patients increased in some cases by 12.5 - 50 micrograms per day (Table 4).
In patients of the study group, the dose of substitution therapy for the period of six months of treatment in 4 cases did not change, in 26 patients it decreased by 12.5 and in 3 cases it increased by 12.5 micrograms per day. After 3 years of treatment, in 13 patients the dose of substitution therapy decreased in some cases by 12.5 or 25 micrograms per day, in 18 patients it remained the same, and in 2 patients the substitution therapy was not expedient (Table 4, $\mathrm{p}<0.05)$.

\section{Conclusions}

Comprehensive treatment of patients suffering from AIT with hypothyroidism with the use of thyroxine, antioxidant and lymph drainage therapy improves the structure of the gland. This treatment reduces the activity of peroxide oxidation and pro-inflammatory cytokines, increases the level of antioxidant protection enzymes, normalizes the number of aniline-positive lymphocytes and improves lymphatic drainage and hormone-producing function of the gland.

\section{Compliance with Ethics Requirements:}

„The authors declare no conflict of interest regarding this article"

"The authors declare that all the procedures and experiments of this study respect the ethical standards in the Helsinki Declaration of 1975, as revised in 2008(5), as well as the national law. Informed consent was obtained from all the patients included in the study"

"No funding for this study" 


\section{References}

1. Vanderpump MPJ. The epidemiology of thyroid disease. British Medicine Bulletin. 2011; 99(1):39-51.

2. Effraimidis G, Wiersinga WM. Mechanisms in endocrinology: autoimmune thyroid disease: old and new players. Eur J Endocrinol. 2014;170:241-52.

3. Garber JR, Cobin RH, Gharib H, et al. Clinical practice guidelines for hypothyroidism in adults: cosponsored by the American Association of Clinical Endocrinologists and the American Thyroid Association. Endocr Pract. 2012;18(6):988-1028.

4. Caturegli P, De Remigis A, Rose NR. Hashimoto thyroiditis: clinical and diagnostic criteria. Autoimmun Rev. 2014;13:391-7.

5. Sheremet MI, Shidlovskyi VO, Sydorchuk LP. Analysis of a process of peroxidation, caspase- 3 and caspase- 8 in patients with autoimmune thyroiditis. Journal of Education, Health and Sport. 2015;5(11):117-125.

6. Fernández V, Tapia G, Varela P, Romanque P, Cartier-Ugarte D, Videla LA. Thyroid hormone-induced oxidative stress in rodents and humans, a comparative view and relation to redox regulation of gene expression. Comp. Biochem. Physiol. 2005, C 142:231-239.

7. Ohye H, Sugawara M. Dual oxidase, hydrogen peroxide and thyroid diseases. Experimental Biology and Medicine. 2010;235(4):424-433.

8. Venditti P, Di Meo S. Thyroid hormone-induced oxidative stress. Cellular and Molecular Life Sciences. 2006;63(4):414434.

9. Erdamar H, Demirci H, Yaman H, et al. The effect of hypothyroidism, hyperthyroidism, and their treatment on parameters of oxidative stress and antioxidant status. Clin Chem Lab Med. 2008;46(7):1004-10.

10. Reddy VS, Gouroju S, Suchitra MM, et al. Antioxidant defense in overt and subclinical hypothyroidism. Horm Metab Res. 2013;45(10):754-8.

11. Ott J, Meusel M, Schultheis A, et al. The incidence of lymphocytic thyroid infiltration and Hashimoto's thyroiditis increased in patients operated for benign goiter over a 31-year period. Virchows Arch. 2011;459(3):277-81.

12. Haribabu A, Reddy VS, Pallavi C, et al. Evaluation of protein oxidation and its association with lipid peroxidation and thyrotropin levels in overt and subclinical hypothyroidism. Endocrine. 2013;44(1):152-157.

13. Santi A, Duarte MMMF, Moresco RN, et al. Association between thyroid hormones, lipids and oxidative stress biomarkers in overt hypothyroidism. Clinical Chemistry and Laboratory Medicine. 2010;48(11):1635-1639.

14. Santi A, Duarte MMMF, de Menezes CC, Loro VL. Association of lipids with oxidative stress biomarkers in subclinical hypothyroidism. International Journal of Endocrinology. 2012;2012:7.

15. Baskol G, Atmaca H, Tanriverdi F, Baskol M, Kocer D, Bayram F. Oxidative stress and enzymatic antioxidant status in patients with hypothyroidism before and after treatment. Experimental and Clinical Endocrinology $\mathcal{E}^{\circ}$ Diabetes. 2007;115(8):522-526.
16. Dukan S, Farewell A, Ballesteros M, Taddei F, Radman M, Nyström T. Protein oxidation in response to increased transcriptional or translational errors. PNAS. 2000;97:5746-9.

17. Joly AL, Wettstein G, Mignot G, Ghiringhelli F, Garrido C. Dual role of heat shock proteins as regulators of apoptosis and innate immunity. J Innate Immun. 2010;2(3):238-47.

18. Rieben C, Segna D, da Costa BR, et al. Subclinical thyroid dysfunction and the risk of cognitive decline: a meta-analysis of prospective cohort studies. J Clin Endocrinol Metab. 2016; 101(12):4945-54.

19. Chaker L, Baumgartner C, den Elzen WP, et al. Subclinical hypothyroidismand the risk of stroke events and fatal stroke: An individual participant data analysis. J Clin Endocrinol Metab. 2015;100(6):2181-91.

20. Ramos-Levi AM, Marazuela M. Pathogenesis of thyroid autoimmune disease: the role of cellular mechanisms. Endocrinol Nutr. 2016;63(8):421-9.

21. Pearce SH, Brabant G, Duntas L, et al. 2013 ETA Guideline: Management of Subclinical Hypothyroidism. Eur Thyroid J. 2013;2(4):215-28.

22. Shi Y, Wang H, Su Z, et al. Differentiation imbalance of Th1/Th17 in peripheral blood mononuclear cells might contribute to pathogenesis of Hashimoto's thyroiditis. Scand J Immunol. 2010;72(3):250-5.

23. Akinci B, Comlekci A, Yener S, et al. Hashimoto's thyroiditis, but not treatment of hypothyroidism, is associated with altered TGFbeta1 levels. Arch Med Res, 2008, 39(4):397-401.

24. Chen K, Wei Y, Sharp GC, Braley-Mullen H. Decreasing TNF-alpha results in less fibrosis and earlier resolution of granulomatous experimental autoimmune thyroiditis. $J$ Leukoc Biol, 2007, 81(1):306-314.

25. Mullur R, Liu YY, Brent GA. Thyroid hormone regulation of metabolism. Physiol Rev. 2014;94(2):352-82

26. Tajiri J. Endocrine diseases: progress in diagnosis and treatments. Topics: III. Thyroid gland; 2. The management approaches to thyroid nodules discovered inci-dentally on diagnostic imaging. Nihon Naika Gakkai Zasshi. 2014;103(4):862-9.

27. Sheremet MI, Sydorchuk LP, Shidlovskyi VO, et al. Remote results of hemithyroidectomy and their prognostication in patient with unilateral nodular goiter combined with autoimmune thyroiditis. Arch Balk Med Union. 2018;53(1):41-46.

28. Sheremet MI. Optimization of complex treatment of patients with nodal forms of goiter on the background of autoimmune thyroiditis and prophylaxis of postoperative complications. Medical forum. 2017;12 (12): 125-129. [in Ukrainian])

29. Venditti P, Di Stefano L, Di Meo S. Vitamin E management of oxidative damage-linked dysfunctions of hyperthyroid tissues. Cellular and Molecular Life Sciences. 2013;70(17):31253144.

30. Hwang S, Byun JW, Yoon JS, et al. Inhibitory effects of $\alpha$-lipoic acid on oxidative stress-induced adipogenesis in orbital fibroblasts from patients with Graves ophthalmopathy. Medicine (Baltimore) 2016;95(2):e2497.

31. Gevorkyan AG, Tsogoyev AS. Application of complex homeopathic preparations in the therapy of chronic autoimmune thyroiditis. Bulletin of New Medical Technologies. 2007: 14(3):102-104. [in Russian] 